\title{
DETERMINANTS OF SOUTH AFRICA-US INTRA-INDUSTRY TRADE IN SERVICES: A WILD BOOTSTRAP DYNAMIC PANEL DATA ANALYSIS ${ }^{1}$
}

\author{
MOSES MUSE SICHEI, CHRIS HARMSE AND FRANS KANFER
}

\begin{abstract}
The study attempts to empirically identify factors that determine South Africa-US intra-industry trade (IIT) in selected services during the period 1994-2002. The study utilises Liu-DavidsonFlachaire wild bootstrap, which is robust to heteroscedasticity and provides estimates of the degree of parameter bias. The empirical results, in principle, show that South Africa-US IIT in the selected services is determined by factors similar to goods-based "North-South" IIT studies. Specifically, differences in per capita income and differences in market size negatively affect IIT. The study also indicates that US foreign direct investment in South Africa positively contributes to the unaffiliated IIT in services.

Keywords: Intra-industry trade, dynamic panel data, wild bootstrap
\end{abstract}

\section{INTRODUCTION}

The steady growth of the services sector's contribution to Gross Domestic Product (GDP) and employment is a characteristic feature of most modern economies. The increase in the contribution of services is attributed to a revolution in information communication technology (ICT) and liberalisation the in context of the General Agreement on Trade in Services (GATS). In South Africa, its contribution to GDP rose from 50\% in 1990 to $58 \%$ in 2002 while its share in employment increased from $56 \%$ in 1990 to $65 \%$ by 2002 (UNCTAD, 2004a).

What is international trade in services? Lee and Lloyd (2002:160) define international trade in services in two ways. Firstly, services are economic flows that take place between residents and nonresidents of an economy. This is attributed to the International Monetary Fund's edition 5 of the Balance of Payments manual, hereafter referred to as "BMP5" (International Monetary Fund, 1993). Secondly, Article 1 of GATS (in World Trade Organisation, 2002:286-287) defines trade in service using four modes of supply: cross-border supply (mode 1), consumption abroad (mode 2), commercial presence (mode 3) and presence of natural persons (mode 4). Lee and Lloyd (2002:161) argue that most trade economists currently think in terms of GATS modes of supply. However, no

\footnotetext{
${ }^{1}$ This is part of a PhD (Economics) thesis for the lead author. Financial support from the African Economic Research Consortium (AERC) is gratefully acknowledged. The views expressed in this paper do not necessarily reflect the opinion of the University of Pretoria.
} 
statistics of services trade by GATS modes are available in most countries (including South Africa) since BMP5 is still the basis of data collection. ${ }^{2}$

Despite its dominance in national output and job creation, services account for less than a quarter of total trade in South Africa and the US (the leading producer and exporter of services in the world) due to its limited tradability and unreliable data. Nonetheless, there are reasons to expect its increased dominance in international trade in future. Firstly, ICT coupled with increasing prevalence of electronic commerce, continue to enhance the tradability (storability and transportability) of services. Secondly, more services sectors are being liberalised through multilateral trade negotiations under the GATS framework, widening the scope for trade. Indeed, according to UNCTAD (2004b), foreign direct investment (FDI) is increasingly shifting towards services.

The enhanced internationalisation of services has two opposite economic welfare implications for South Africa. On one hand, the increase generates standard comparative advantage gains (specialisation and exchange) and non-comparative advantage gains (procompetitive, exploitation of economies of scale, increased variety and lower factor market adjustment costs of trade). Additionally, liberalisation of trade in services could be consistent and complementary to sustainable development in the context of the Doha Development Agenda. On the other hand, the increased tradability may lead to higher factor market adjustment costs along the lines of Stolper-Samuelson or the vertical differentiation model of Flam and Helpman (1987).

However, to understand the benefits and costs of South Africa's trade in services with the US (South Africa's leading exports destination of services in the Organisation for Economic Co-operation and Development (OECD) countries) calls for a need to disentangle "intraindustry trade" (IIT) from "inter-industry trade" because they have different causes and consequences. Inter-industry trade in services entails exports of one type of service in exchange for another (i.e. from different service industries). Using a definition attributed to Grubel and Lloyd (1975:20), IIT in services is a simultaneous exports and imports of services that belong to the same industry.

The study focuses on the determinants of South Africa-US unaffiliated IIT in selected services during the period 1994-2002. The choice of the US among many of South Africa's trading partners is motivated by the fact that it is the latter's leading exports destination in the OECD countries, availability of bilateral international trade data (US Bureau of Economic Analysis), and the need to complement other research (such as Hodge and Nordas, 2001; Walley and Keith, 2003) in informing trade policy in the services sector such as the SACU ${ }^{3}$ US Free Trade Agreement negotiations.

The novelty of this paper is in attempting to find the empirical determinants of South Africa-US unaffiliated ${ }^{4}$ IIT in selected services during the period 1994-2002 utilising wild bootstrapping in the context of panel data. The paper is in the spirit of other research focusing on "North-South" trade in services (Sapir, 1985; Clark and Stanley, 1999; Kunin and Zigic, 2003).

\footnotetext{
${ }^{2}$ While this framework categorise service industries in a way that is meaningful economically, it does not show the origin and destination of services trade.

${ }^{3}$ The Southern African Customs Union came into existence in 1969 and includes the following countries South Africa, Botswana, Lesotho, Namibia and Swaziland.

${ }^{4}$ This is trade flow, which does not involve related parties. For instance, service trade between Coca Cola South Africa and its parent company in the US is excluded.
} 
The empirical results support modern trade theories with regard to dissimilarities in demand structure, degree of market openness and economies of scale. Firstly, dissimilarities in demand structure between South Africa and the US reduce the level of trade in differentiated services. Secondly, economies of scale play a significant role in determining the level of unaffiliated IIT in the selected services. Finally, US FDI in South Africa increases unaffiliated IIT

The rest of the paper is organised as follows. Section 2 provides a theoretical basis for the determinants of unaffiliated IIT in services. Section 3 deals with model specification while section 4 focuses on the data. Section 5 is devoted to the estimation methodology. Section 6 presents the estimation results and discussion. The final section is devoted to conclusions.

\section{THEORETICAL FRAMEWORK}

There is a great diversity of models focusing on differentiated IIT, as well as alternative market structures such as monopolistic competition leading to Chamberlin-Heckscher-Ohlin (CHO) models and oligopoly. The determinants and predictions of these models are different while in some cases it is quite difficult to discriminate between them (Andresen, 2003). Despite these inherent problems, many empirical studies of IIT have tried to identify those features that are common to all, or to most of these models. However, in view of data problems, the features are subject to measurement errors.

Andresen (2003), using a classification proposed by Greenaway and Milner (1989), provides a survey of the determinants of IIT in goods. On the one hand, there are countryspecific determinants, which are divided into five broad categories: economic development, market size, geographic proximity, economic integration and barriers to trade. On the other hand, there are industry-specific determinants which cover the categories of service differentiation, economies of scale, market structure, product life cycle and the role of multinational corporations.

Most of the empirical studies of IIT have been restricted to trade in goods. However, there are a few studies dealing with services trade. Lee and Lloyd (2002) conduct an empirical analysis of inter-country differences in IIT in services for the OECD. Using data from the 1998 edition of Services Statistics on International Transactions (1987-1996), the study found that IIT was uniformly high in 20 OECD countries and nine service industries, and was stable over time. However, for 17 out of the 20 countries, combining goods and services trade reduces the magnitude of trade imbalances. This in turn raises the level of IIT because of the negative empirical relationship between the level of IIT and trade imbalance.

Li et al. (2003) measured the extent of IIT for insurance services for the US with her trading partners in 1995 and 1996. The study found that the IIT model of insurance services captured key factors that are important in increasing the volume of IIT in insurance services. These include differences in per capita income, market concentration in goods and services, trade imbalance, market size, FDI, affiliated trade and market openness.

\section{MODEL SPECIFICATION}

In constructing the model, the study combines the "country-specific" and "industry-specific" determinants highlighted in Greenaway and Milner (1989) in one equation; 


$$
I I T_{i t}=f\left(I I T_{i t-1}^{+}, \bar{P}_{t}, \bar{S}_{i t}, \stackrel{+}{\Delta E_{t}}, \stackrel{+}{D} S A_{i t}, T \overline{T S}_{i t}, \stackrel{+}{\operatorname{U}} S_{i t}, \overline{F I}_{i t}\right)
$$

$I I T_{i t}$ is the unadjusted GL index for IIT in unaffiliated services computed using equation 2.6 in Grubel and Lloyd (1975:22). $P_{t}$ is an index of the difference in nominal per capita income between South Africa and US, used as a proxy for dissimilarities in demand structure. $S_{i t}$ is an index of the difference in market size between the US and South Africa and is used as a proxy for economies of scale. $\Delta E_{t}$ is the change in nominal Rand-US dollar exchange rate (Rand/\$). $D S A_{i t}$ is an index of the degree of economic freedom (deregulation)

in South Africa. $T S A_{i t}$ and $T U S_{i t}$ are Hoekman (1995)-type services trade openness indices in terms of market access and national treatment for all modes of supply in South Africa and the US, respectively. $F I_{i t}$ is US foreign direct investment in South Africa.

The subscript $i$ denotes the fth service sector ( $i=$ Airfreight services; Education services; Financial services; Legal services; Management, Consulting and Public Relations services; Ocean Freight services; Ocean Port services; Research \& Development, Royalties and Fees; Telecommunication services and Travel or tourism services). The subscript $t$ denotes the $\mathrm{fth}$ year $(t=1994,1995,2002)$.

Most econometric studies of the determinants of IIT employ the ordinary least squares (OLS) or its variants. The GL index, most commonly used in empirical studies, varies between 0 and 1 but OLS may provide forecasts which are not within the 0 to 1 range. Using the approach in Balassa and Bauwens (1987), equation 1 is estimated as;

$y_{i t}=\alpha+\beta_{1} y_{i t-1}+\beta_{2} P_{t}+\beta_{3} S_{i t}+\beta_{4} \Delta E_{t}+\beta_{i 5} D S A_{i t}+\beta_{6} T S A_{i t}+\beta_{7} T U S_{i t}+\beta_{8} F I_{i t}+\varepsilon_{i t}$

Where $y_{i t}=\log \left(\frac{I I T_{i t}}{1-I I T_{i t}}\right)$ i.e. the odds ratio of IIT.

The expected signs are:

$$
\beta_{1}>0, \beta_{2}<0, \beta_{3}<0, \beta_{4}>, \beta_{i 5}>0, \beta_{6}<0, \beta_{7}>0, \beta_{8}<0
$$

The disturbance term is specified as a two-way error component model,

$\varepsilon_{i t}=\mu_{i}+\lambda_{t}+v_{i t}$

$\mu_{i}$ denotes service-specific effects, $\lambda_{t}$ denotes year-specific effects, and $\nu_{i}$ is an idiosyncratic disturbance term, which varies across services and time. No normality assumption is made about this error term in finite samples since statistical inference is done using nonparametric bootstrapping techniques.

\section{THE DATA}

$I I T_{i t}$ : Mirrored $^{5}$ unaffiliated services trade data are used to calculate South Africa-US adjusted GL index. The data are taken from the United States Bureau of Economic

' Mirrored data refers to the fact that data is collected from the trading partner's side. This means that US imports are treated as South Africa's exports and vice versa. There are limitations in this approach such as under-invoicing. However, it is hoped that the US has an efficient system of recording international transactions. 
Analysis (http://www.bea.gov/bea/di/1001serv/intlserv.htm). The descriptions of the services are in US Department of Commerce (1998). The data is in nominal US dollars (millions) and is not deflated due to lack of sectoral deflators.

$P_{t}:$ Nominal GDP per capita (US\$) for South Africa and US are collected from the IMF's International Financial Statistics. Instead of taking absolute values of inter-country differences $m$ per capita incomes, equation 4 in Balassa and Bauwens (1987:927) is used to calculate relative differences that take values between 0 and 1 .

$S_{i t}$ : Data used to calculate differences in market size was collected from different sources. Proxies for market size variable differ from service to service as shown in Table 1 below.

Equation 4 in Balassa and Bauwens (1987:927) is used to calculate an index of relative inequality which is robust to size bias.

$\Delta E_{i t}$ : The change in Rand-US dollar exchange rate (Rand/\$). The data is collected from the IMF International Financial Statistics.

$D S A_{i t}$ : Index of Economic Freedom published by the Fraser Institute (http://www. freetheworld.com/) is used as a proxy to measure the degree of deregulation in a particular service sector in South Africa. The different proxies are shown in Table 2 below.

$T S A_{i t}$ and TUS $S_{i t}$ : Index of trade openness in the services sector and are constructed using Hoekman-(1995) frequency methods (See Sichei, 2005). This is to some extent related to the economic freedom index. However, these indices are more specific to international trade in services.

Table 1. Proxies for market size

\begin{tabular}{|c|c|c|}
\hline Service & Proxy of market size & Source \\
\hline Air freight & Air transport freight (million tons per $\mathrm{KM}$ ) & World Development Indicators \\
\hline Education & $\begin{array}{l}\text { South African students enrolled in US tertiary } \\
\text { institutions and vice versa }\end{array}$ & Open doors. http://opendoors.iienetwork.org/ \\
\hline Financial services & Foreign assets of banking and financial institutions & IMF International Financial Statistics \\
\hline Legal services & Civil cases of debt & STATSA and Federal Court \\
\hline $\begin{array}{l}\text { Management, consulting and } \\
\text { public relations }\end{array}$ & $\begin{array}{l}\text { Data on other services in UNCTAD services trade } \\
\text { data }\end{array}$ & UCTAD \\
\hline Ocean freight & $\begin{array}{l}\text { Merchant shipping fleets: total ( } 000 \text { gross registered } \\
\text { tons) }\end{array}$ & UN Statistical Yearbook \\
\hline Ocean port services & $\begin{array}{l}\text { Merchant shipping fleets: total }(000 \text { gross registered } \\
\text { tons) }\end{array}$ & UN Statistical Yearbook \\
\hline $\begin{array}{l}\text { Research \& development, and } \\
\text { testing services }\end{array}$ & Trademarks and patents granted & $\begin{array}{l}\text { World Intellectual Property Organisation } \\
\text { (WIPO) http://www.wipo.int }\end{array}$ \\
\hline Telecommunications & $\begin{array}{l}\text { Fixed telephone lines and mobile subscribers per } \\
1,000 \text { people }\end{array}$ & World Development Indicators \\
\hline Travel & Number of tourist arrivals & World Development Indicators \\
\hline
\end{tabular}

Source: Authors' construction.

Table 2. Degree of deregulation (economic freedom)

\begin{tabular}{ll}
\hline Sector & Proxy for the degree of deregulation \\
Air freight services & Regulatory trade barriers \\
Education and training services & Country overall rating of economic freedom by Fraser institute \\
Financial services & Access to sound money \\
Legal services & Integrity of the legal system \\
Management consulting and public relations services & Freedom to exchange with foreigners \\
Ocean freight services & Regulatory trade barriers \\
Ocean port services & Regulatory trade barriers \\
Research \& development and testing services & Protection of intellectual property rights \\
Telecommunication services & Freedom to exchange with foreigners \\
Travel services & Country overall rating of economic freedom by Fraser institute \\
\hline
\end{tabular}


$F I_{i t}$ : Mirrored sectoral FDI (US\$mn) is collected from the US Bureau of Economic Analysis. FDI includes the initial transaction between two entities and all subsequent financial transactions between them and among affiliated enterprises, both incorporated and unincorporated.

\section{THE ESTIMATION METHODOLGY}

Mirrored data from the US Bureau of Economic Analysis (US dollars) are sorted to identify "genuine IIT" using a methodology pioneered by Abd-el-Rahman (1991). Consequently IIT is a structural feature of trade in a particular service sector if the minority service flow ${ }^{6}$ is at least $12 \%$ of the majority service flow.

The panel data model in equation 2 is estimated within a general linear model (GLM) framework. GLM is an extension of the multivariate regression model in a number of ways. Firstly the GLM allows for linear transformation or linear combinations of multiple dependent variables. This provides the ability to analyse effects or repeated measures and thus encapsulates a panel data model. Secondly since GLM uses generalised inverses, it can provide solutions to normal equations when the regressors are linearly dependent.

The paper uses bootstrap methodology introduced by Efron (1979) to conduct hypothesis tests. Bootstrapping is a statistical method of estimating the sampling distribution of an estimator by resampling with replacement from the original sample with a view to deriving robust estimates of standard errors and confidence intervals of population parameters. The use of bootstrap is predicated on the fact that first-order asymptotic theory approximation (classical statistical inference), commonly used in econometrics, assumes that a statistic has a known sampling distribution ${ }^{7}$ and readily available method of computing its parameters. If any of these two assumptions fail, the first-order asymptotic theory approximation approach to statistical inference will be flawed. This calls for bootstrapping, which enables robust statistical inference when any of the two or both assumptions do not hold. The study uses bootstrap for three reasons. Firstly, as pointed out by Horowitz (2001) bootstrap provides a better Type I error approximation than the first-order asymptotic theory. Secondly, it can estimate the degree of coefficient bias. This is quite important in detecting potential endogeneity in the dynamic panel data specification used in this study. Finally, it can be used as a check on the adequacy of the first-order asymptotic theory approximation.

Alternative dynamic panel estimators are the first different generalised method of moments (GMM) estimator of Arellano and Bond (1991), the system GMM estimator of Arrellano and Bover (1995) and Everaert and Pozzi (2004). Our bootsrap-based approach is in the spirit of Everaert and Pozzi (2004) in dealing with potential endogeneity problems.

${ }^{6}$ This terminology is used to refer to either exports or imports whenever there is a deficit or surplus in bilateral trade in services. If South Africa's service imports from the US are lower than service exports for the same period, imports are described as "minority service flow" while exports are referred to as "majority service flow".

${ }^{7}$ For instance, in a linear regression model, its error term is assumed to be normally, identically and independently distributed with zero mean and constant variance. 
The standard error components model given in equation 4 assumes that the regression disturbances are homoscedastic with the same variance across time and individual service sectors. This is a restrictive assumption in South Africa-US unaffiliated I IT covering diverse service sectors.

Baltagi (2001) warns that assuming homoscedastic disturbances when heteroscedasticity exists will result in consistent but inefficient estimates of the regression coefficients. Additionally, the standard errors of these estimates will be biased unless a robust standard error is computed which corrects for the possible presence of heteroscedasticity.

Bootstrap methods rely on simulation to approximate finite-sample distribution of pivotal test statistic. A statistic is pivotal if its sampling distribution does not depend on unknown parameters. In order for such methods to be reasonably accurate, it is desirable that the data generating process (DGP) used for drawing bootstrap samples should be as close as possible to the true DGP that generated the observed data, assuming that the DGP actually satisfies the null hypothesis. This presents a serious problem if the regression model has errors with heteroscedasticity of unknown form, i.e. if the form of heteroscedasticity is unknown, it cannot be imitated in the bootstrap DGP

Davison and Hinkley (1998:272) argue that the best approach to deal with heteroscedasticity of unknown form is wild bootstrap. Wild bootstrap estimates variances from individual residuals. Mammen (1993:257) notes that it is called wild bootstrap because n factorial ${ }^{8}$ different distributions of residuals are estimated by only n observations. Wild bootstrap was originally proposed by Liu (1988) following the work of Wu (1986) and Beran (1986). Liu (1988) established the ability of the wild bootstrap to provide refinements for the linear regression model with heteroscedastic errors and further evidence was provided by Mammen (1993), Davidson and Flachaire (2001) and Flachaire (2003). Mammen (1993) showed that under some regularity conditions, wild bootstrap is asymptotically justified in the sense that the asymptotic distributions of the various statistics are the same as the asymptotic distributions of their wild counterparts.

In the wild bootstrap literature, two distributions of the error term are commonly used. Mammen (1993) suggested the following two-point distribution:

$$
F_{1}: t_{i}=\left\{\begin{array}{l}
-\frac{(\sqrt{5}-1)}{2}, \text { with } \\
\frac{(\sqrt{5}+1)}{2}, \text { with probability } p=\frac{(\sqrt{5}+1)}{2 \sqrt{5}} \\
\text { probability } 1-p
\end{array}\right.
$$

Liu (1988) introduced the use of Rademacher distribution in wild bootstrap. Rademacher distribution, named after Hans Rademacher, is a discrete probability distribution which has a $50 \%$ chance for either 1 or -1 . The probability mass function (pmf) of this distribution is:

\footnotetext{
${ }^{8}$ Written as $n$ ! meaning $n X(n-1) X(«-2) \ldots X 1$
} 


$$
F_{2}: t_{i}=f(k)=\left\{\begin{array}{lll}
\frac{1}{2} & \text { if } & k=1 \\
\frac{1}{2} & \text { of } & k=-1 \\
0 & \text { Otherwise }
\end{array}\right.
$$

As pointed out in Liu (1988) and Mammen (1993:257), this lattice distribution satisfies three requirements:

$E\left(t_{i t}\right)=0, E\left(t_{i t}^{2}\right)=1 \quad$ and $\quad E\left(t_{i t}^{3}\right)=1$

The first condition in equation 7 shows that the Rademacher distribution centres the bootstrap statistic around zero. The second condition states that the Rademacher distribution centres the variance around 1 while the last condition corrects for skewness in the Edgeworth expansion of the sampling distribution of the parameter estimates.

Davidson and Flachaire (2001) show that, on the basis of theoretical analysis and simulation experiments, wild bootstrap tests based on the Rademacher distribution, $F_{2}$, usually performs better in finite samples than those based on the $F_{1}$. A SAS bootstrap macros is used to perform the Liu-Davidson-Flachaire wild bootstrap using the following algorithm:

Firstly, equation 2 is estimated using GLM procedure in SAS and residuals, $e_{i t}$, generated. The second step entails transforming the residuals using the second form of Mackinnon and White (1985) heteroscedasticity consistent covariance matrix estimator (HCCME):

$a_{i t} e_{i t}=\left(\frac{1}{\sqrt{1-h_{i t}}}\right) v_{i t}$

Where $a_{i t} e_{i t}$ are the modified residuals, $a_{i t}=\frac{1}{\sqrt{1-h_{i t}}}, \quad h_{i t}=X_{i t}\left(X^{\prime} X\right)^{-1} X_{i t}^{\prime}$ i.e. the leverage is the jth element of the orthogonal projection matrix on to the span of the columns of $\mathrm{X} . v_{i t}$ is the idiosyncratic error term in equation 4 . This adjustment compensates for the fact that the OLS residuals (and thus GLM) tend to understate the true errors.

In the third step, since the SAS software does not have a customised Rademacher distribution in equation 6 , this was done manually. This entailed generating a series, which is a sequence that alternate between 1 and -1 . Since there are 90 observations in total, 45 of take the value of 1 while the remaining take value -1 effectively constructing a Rademacher variable.

Fourthly, resampling with replacement is done for the generated variable following the $F_{2}$ distribution.

Fifthly, this is multiplied with the modified residuals in equation 8 as follows:

$$
v_{i t}^{*}=a_{i t} e_{i t} t_{i t}
$$


Sixthly, bootstrap vector of response variables, $\left(y_{i t}^{*}\right)_{b}$, are generated by adding the resampled vector of residuals for that sector to the vector of fitted response as follows:

$\left(y_{i t}^{*}\right)_{b}=\hat{y}_{i t}+v_{i t}^{*}$

Seventhly, bootstrapped response variables are regressed using GLM on the fixed explanatory variables to estimate a bootstrapped vector of coefficients, $\hat{\beta}_{b}^{*}$.

$\left(y_{i t}^{*}\right)_{b}=\hat{\beta}_{b}^{*} z_{i t}+\eta_{i t}$

Eighthly, this procedure from the first to the sixth step is repeated B times (in this case, B = $3,000)$. The bootstrapped regression coefficients for each resample are placed in a $(3,000 \mathrm{X}$ 36) matrix. Each column in this matrix is converted into an estimate of the sampling distribution of the $\hat{\beta}$ by placing a probability of $1 / 3,000$ on each value of $\hat{\beta}_{b}^{*}$.

Ninthly, the bias of the estimated coefficients is computed in line with Mooney and Duval, (1993:30-33) as follows:

$\operatorname{Bias}(\hat{\beta})=\hat{\beta}-\hat{\beta}_{(.)}$

Where $\hat{\beta}_{(.)}^{*}=\frac{\sum_{b=1}^{B} \hat{\beta}_{b}^{*}}{B}$

This step does not only determine whether endogeneity is a serious problem but it also informs the decision of which method to use in constructing confidence intervals.

Finally, confidence intervals are constructed using the percentile method (Davison and Hinkley 1998:202-205). This entails sorting the bootstrap parameters in ascending order and then selecting the appropriate percentiles. For instance, with 3,000 replications and using the 95\% confidence interval, the bootstrapped parameter number 75 is selected as the lower confidence limit value and number 2925 as the upper confidence limit value in the empirical distribution function (EDF). Hypothesis tests can then be performed.

\section{ESTIMATION RESULTS AND DISCUSSION}

(a) First-Order Asymptotic Theory Results

The panel data model in equation 2 is estimated within a GLM framework. Table 3 presents the results. The results are referred to as first-order asymptotic theory because they use firstorder asymptotic distribution of the test statistic under the null to approximate Type I critical values. The rationale for this approximation is the fact that most test statistics in econometrics are asymptotically pivotal because their asymptotic distributions do not depend on unknown population parameters when the null hypothesis being tested is true. On the basis of this, an approximate Type I critical value can be obtained from asymptotic distribution theory without knowledge of where the true DGP is in the set specified by the null hypothesis.

In view of the fact that these results form the basis of bootstrapping, a number of diagnostic tests were performed. These include test of equality of variance and detection of influential observations. 
Table 3. First-order asymptotic theory panel data estimation results

\begin{tabular}{|c|c|c|c|}
\hline \multirow[t]{2}{*}{ Independent variables and service sector } & \multicolumn{3}{|c|}{ First-order asymptotic theory results } \\
\hline & Estimate & Std error & p-value \\
\hline Intercept & $73.496^{* * *}$ & 19.278 & 0.000 \\
\hline$y_{i-1}$ & $-0.385^{* * *}$ & 0.078 & 0.000 \\
\hline Difference in per capita income & $-126.738^{* *}$ & 42.887 & 0.004 \\
\hline Difference in market size & $-16.428^{* *}$ & 6.528 & 0.015 \\
\hline US foreign direct investment in SA & $29.593^{* *}$ & 14.562 & 0.047 \\
\hline Nominal exchange rate (Rand/\$) & $67.154^{*}$ & 36.059 & 0.068 \\
\hline Openness to services trade in SA & -6.679 & 4.999 & 0.187 \\
\hline Openness to services trade in the US & -1.128 & 3.644 & 0.758 \\
\hline \multicolumn{4}{|l|}{ Deregulation in South Africa: } \\
\hline Air freight services & -2.063 & 1.425 & 0.154 \\
\hline Education and training services & $2.322^{*}$ & 1.376 & 0.097 \\
\hline Financial services & 1.505 & 1.376 & 0.279 \\
\hline Legal services & -0.391 & 2.984 & 0.896 \\
\hline Management, consulting and public relation services & $4.337^{*}$ & 2.288 & 0.063 \\
\hline Ocean freight services & $-4.647^{* *}$ & 1.425 & 0.002 \\
\hline Ocean port services & $8.802^{* *}$ & 2.447 & 0.001 \\
\hline Research development and testing services & 3.153 & 2.513 & 0.215 \\
\hline Telecommunications services & $-8.474^{* *}$ & 3.356 & 0.015 \\
\hline Travel (tourism) services & 1.287 & 1.415 & 0.367 \\
\hline \multicolumn{4}{|l|}{ Service-specific fixed effects: } \\
\hline Air freight services & $24.214^{*}$ & 8.685 & 0.007 \\
\hline Education and training services & -11.549 & 8.383 & 0.174 \\
\hline Financial services & -3.949 & 9.046 & 0.664 \\
\hline Legal services & -6.708 & 14.712 & 0.650 \\
\hline Management, consulting and public relation services & $-22.740^{*}$ & 12.295 & 0.070 \\
\hline Ocean freight services & $40.920^{* * *}$ & 8.558 & 0.000 \\
\hline Ocean port services & $-56.507^{* * *}$ & 14.388 & 0.000 \\
\hline Research development and testing services & -15.230 & 17.654 & 0.392 \\
\hline Telecommunication services & $54.305^{* *}$ & 17.818 & 0.004 \\
\hline Travel (tourism) services ${ }^{2}$ & -2.756 & & \\
\hline \multicolumn{4}{|l|}{ Time-specific effects: } \\
\hline 1994 & $-4.383^{* *}$ & 1.777 & 0.017 \\
\hline 1995 & -2.152 & 2.560 & 0.404 \\
\hline 1996 & $-8.805^{* *}$ & 3.590 & 0.017 \\
\hline 1997 & -0.866 & 1.514 & 0.570 \\
\hline 1998 & $-4.648^{* *}$ & 2.085 & 0.030 \\
\hline 1999 & $4.314^{*}$ & 2.316 & 0.068 \\
\hline 2000 & $6.114^{* *}$ & 2.070 & 0.005 \\
\hline 2001 & $4.731^{* *}$ & 2.098 & 0.028 \\
\hline $2002^{2}$ & 5.695 & & \\
\hline \multicolumn{4}{|l|}{ Diagnostic statistics } \\
\hline Rsquare & 0.684095 & & \\
\hline Adjusted R-square & 0.502806 & & \\
\hline F-statistic & $3.50(0.000)$ & & \\
\hline Durbin-h & 1.0008 & & \\
\hline First-order autocorrelation coefficient & -0.0707 & & \\
\hline
\end{tabular}

Notes: Sample period: 1994-2002.

${ }^{2}$ The effects of travel service-effects are estimated as minus the sum of other service effects. The same applies to the time-specific effects of 2002.

$*, * *$, and ${ }^{* * *}$ imply significance at $10 \%, 5 \%$ and $1 \%$, respectively.

The test of equality of variances is done using Levene's test (Levene I960). Levene's test checks whether the variances of two or more populations are equal. Table 4 shows that the variances of the residuals from the different service sectors are statistically different (i.e. there is heteroscedasticity).

Influential observations are those observations whose presence in the data can have distorting effect on the parameter estimates and possibly the entire analysis. Outliers are data points that contain unusual dependent values (Mukherjee et al. 1998).

The following observation statistics are used: hat-values, covratio, Dffits and CookD. The hat-value measures the leverage of the regression. This implies that if the hat-value 
Table 4. Tests of equality of residual variances

\begin{tabular}{lcc}
\hline Service sector & Mean & Standard deviation \\
Airfreight & $6.957 \mathrm{e}-14$ & 0.694 \\
Education and training & $4.322 \mathrm{e}-14$ & 1.389 \\
Financial services & $5.035 \mathrm{e}-14$ & 0.736 \\
Legal services & $4.706 \mathrm{e}-14$ & 0.854 \\
Management consulting and public relations services & $3.863 \mathrm{e}-14$ & 0.746 \\
Ocean freight services & $8.091 \mathrm{e}-14$ & 2.533 \\
Ocean port services & $-2.137 \mathrm{e}-14$ & 3.442 \\
Research development and testing services & $6.291 \mathrm{e}-14$ & 0.959 \\
Telecommunications & $6.906 \mathrm{e}-14$ & 1.430 \\
Travel (tourism services & $5.018 \mathrm{e}-14$ & 1.389 \\
Levene's F-test statistic & $2.540(0.013)$ &
\end{tabular}

Note: Type I error probability in brackets.

Source: SAS statistical software output.

Table 5. Liu-Davidson-Flachaire wild bootstrap results (3,000 replications)

\begin{tabular}{|c|c|c|c|c|c|}
\hline Independent variables and service sector & Estimate & Std error & Bias & $\begin{array}{l}\text { Confidence } \\
\text { interval }\end{array}$ & $\begin{array}{l}\text { (Percentile method) } \\
\%\end{array}$ \\
\hline $\begin{array}{l}\text { Intercept } \\
y_{i t-1} \\
\text { Difference in per capita income } \\
\text { Difference in market size } \\
\text { US foreign direct investment in SA } \\
\text { Nominal exchange rate (Rand/\$) } \\
\text { Openness to services trade in SA } \\
\text { Openness to services trade in the US }\end{array}$ & $\begin{array}{r}74.744^{* * *} \\
-0.386^{* * *} \\
-129.108^{* * *} \\
-16.678^{* * *} \\
29.455^{*} \\
68.606^{* *} \\
-6.627 \\
-1.051\end{array}$ & $\begin{array}{r}19.039 \\
0.148 \\
40.751 \\
4.915 \\
18.239 \\
34.245 \\
4.345 \\
1.644\end{array}$ & $\begin{array}{r}-0.066 \\
0.007 \\
0.058 \\
0.051 \\
0.008 \\
-0.042 \\
-0.012 \\
-0.047\end{array}$ & $\begin{array}{c}31.579,124.273 \\
-0.729,-0.062 \\
-220.852,-41.813 \\
-29.183,-4.332 \\
1.284,58.098 \\
3.721,134.201 \\
-13.323,0.308 \\
-3.909,1.730\end{array}$ & $\begin{array}{l}99 \\
99 \\
99 \\
99 \\
90 \\
95 \\
90 \\
90\end{array}$ \\
\hline $\begin{array}{l}\text { Deregulation in South Africa: } \\
\text { Air freight services } \\
\text { Education and training services } \\
\text { Financial services } \\
\text { Legal services } \\
\text { Management, consulting and public relation services } \\
\text { Ocean freight services } \\
\text { Ocean port services } \\
\text { Research development and testing services } \\
\text { Telecommunications services } \\
\text { Travel (tourism) services }\end{array}$ & $\begin{array}{l}-2.077^{*} \\
2.189^{* *} \\
1.466 \\
-0.324 \\
4.351^{* * *} \\
-4.693^{* * *} \\
8.839^{* *} \\
3.24^{* *} \\
-8.484^{* * *} \\
1.249\end{array}$ & $\begin{array}{l}1.159 \\
1.187 \\
1.053 \\
2.310 \\
2.060 \\
1.899 \\
4.065 \\
1.644 \\
2.248 \\
1.057\end{array}$ & $\begin{array}{r}0.012 \\
0.112 \\
0.037 \\
-0.029 \\
-0.007 \\
0.024 \\
-0.009 \\
-0.053 \\
0.004 \\
0.036\end{array}$ & $\begin{array}{c}-4.026,-0.205 \\
0.024,4.521 \\
-0.285,3.167 \\
-4.020,3.344 \\
0.130,9.301 \\
-9.446,-0.547 \\
1.146,16.462 \\
0.115,6.483 \\
-13.927,-3.288 \\
-0.589,2.937\end{array}$ & $\begin{array}{l}90 \\
95 \\
90 \\
90 \\
99 \\
99 \\
95 \\
95 \\
99 \\
90\end{array}$ \\
\hline $\begin{array}{l}\text { Service-specific fixed effects: } \\
\text { Air freight services } \\
\text { Education and training services } \\
\text { Financial services } \\
\text { Legal services } \\
\text { Management, consulting and public relation services } \\
\text { Ocean freight services } \\
\text { Ocean port services } \\
\text { Research development and testing services } \\
\text { Telecommunication services } \\
\text { Travel (tourism) services }\end{array}$ & $\begin{array}{l}24.280^{* * * *} \\
-10.676^{*} \\
-3.654 \\
-7.167^{*} \\
-22.878^{* * *} \\
41.231^{* * *} \\
-56.715^{* * *} \\
-16.014 \\
54.232^{* * *} \\
-2.639\end{array}$ & $\begin{array}{r}8.084 \\
6.129 \\
5.839 \\
12.795 \\
10.180 \\
15.010 \\
24.558 \\
10.447 \\
12.095\end{array}$ & $\begin{array}{r}-0.008 \\
-0.142 \\
-0.050 \\
0.036 \\
0.014 \\
-0.021 \\
0.008 \\
0.075 \\
0.006\end{array}$ & $\begin{array}{c}5.631,44.193 \\
-20.955,-0.994 \\
-12.887,6.452 \\
-28.433,-1.352 \\
-46.733,-1.352 \\
9.363,73.926 \\
-114.372,-0.412 \\
-33.909,1.438 \\
24.689,83.467\end{array}$ & $\begin{array}{l}99 \\
90 \\
90 \\
90 \\
99 \\
99 \\
99 \\
90 \\
99\end{array}$ \\
\hline $\begin{array}{l}\text { Time-specific effects: } \\
1994 \\
1995 \\
1996 \\
1997 \\
1998 \\
1999 \\
2000 \\
2001 \\
2002^{2}\end{array}$ & $\begin{array}{l}-4.495^{* * *} \\
-2.224 \\
-9.005^{* * *} \\
-0.803 \\
-4.733^{* *} \\
4.437^{* *} \\
6.242^{* * *} \\
4.771^{* * *} \\
5.81\end{array}$ & $\begin{array}{l}1.419 \\
2.274 \\
3.474 \\
1.353 \\
2.090 \\
2.238 \\
2.081 \\
1.643\end{array}$ & $\begin{array}{r}0.079 \\
0.032 \\
0.058 \\
-0.047 \\
0.041 \\
-0.055 \\
-0.062 \\
-0.024\end{array}$ & $\begin{array}{c}-8.569,-1.387 \\
-5.991,1.739 \\
-16.993,-1.806 \\
-3.056,1.224 \\
-8.626,-0.466 \\
0.128,8.618 \\
1.542,11.419 \\
0.968,8.690\end{array}$ & $\begin{array}{l}99 \\
90 \\
99 \\
90 \\
95 \\
95 \\
99 \\
99\end{array}$ \\
\hline
\end{tabular}

Notes: Sample period: 1994-2002.

a The effects of travel service-effects are estimated as minus the sum of other service effects. The same applies to the time-specific effects of 2002.

$*{ }^{* *}$, and ${ }^{* * *}$ imply significance at $10 \%, 5 \%$ and $1 \%$, respectively. 
Table 6. Influential data observations

\begin{tabular}{|c|c|c|c|c|c|c|c|}
\hline$\overline{\text { Obs }}$ & Service industry & Year & Residual & $\mathbf{h}$ & Covratio & Dffits & CookD \\
\hline 1 & Afre & 1994 & -0.155 & 0.436 & 3.449 & -0.091 & 0.000 \\
\hline 2 & Afre & 1995 & 0.417 & 0.316 & 0.744 & 0.173 & 0.001 \\
\hline 3 & Afre & 1996 & -0.518 & 0.294 & 0.260 & -0.200 & 0.001 \\
\hline 4 & Afre & 1997 & -0.650 & 0.265 & 2.415 & -0.229 & 0.001 \\
\hline 5 & Afre & 1998 & 0.326 & 0.299 & 2.723 & 0.128 & 0.000 \\
\hline 6 & Afre & 1999 & 0.544 & 0.277 & 2.526 & 0.199 & 0.001 \\
\hline 7 & Afre & 2000 & 1.456 & 0.377 & 1.744 & 0.728 & 0.015 \\
\hline 8 & Afre & 2001 & -1.228 & 0.408 & 2.131 & -0.671 & 0.013 \\
\hline 9 & Afre & 2002 & -0.193 & 0.446 & 3.496 & -0.117 & 0.000 \\
\hline 10 & Educ & 1994 & 0.102 & 0.720 & 6.954 & 0.155 & 0.001 \\
\hline 11 & Educ & 1995 & -1.914 & 0.354 & 1.129 & -0.899 & 0.022 \\
\hline 12 & Educ & 1996 & 0.144 & 0.318 & 2.860 & 0.060 & 0.000 \\
\hline 13 & Educ & 1997 & -1.329 & 0.443 & 2.031 & -0.805 & 0.018 \\
\hline 14 & Educ & 1998 & -0.906 & 0.341 & 2.399 & -0.405 & 0.005 \\
\hline 15 & Educ & 1999 & 0.637 & 0.262 & 2.416 & 0.223 & 0.001 \\
\hline 16 & Educ & 2000 & 1.610 & 0.261 & 1.443 & 0.565 & 0.009 \\
\hline 17 & Educ & 2001 & 0.386 & 0.335 & 2.837 & 0.169 & 0.001 \\
\hline 18 & Educ & 2002 & 1.270 & 0.325 & 1.921 & 0.543 & 0.008 \\
\hline 19 & Fins & 1994 & -0.043 & 0.801 & 9.852 & -0.097 & 0.000 \\
\hline 20 & Fins & 1995 & -0.182 & 0.443 & 3.486 & -0.110 & 0.000 \\
\hline 21 & Fins & 1996 & -0.349 & 0.421 & 3.265 & -0.197 & 0.001 \\
\hline 22 & Fins & 1997 & 0.531 & 0.448 & 3.252 & 0.324 & 0.003 \\
\hline 23 & Fins & 1998 & -0.300 & 0.370 & 3.037 & -0.146 & 0.001 \\
\hline 24 & Fins & 1999 & 0.639 & 0.274 & 2.452 & 0.232 & 0.002 \\
\hline 25 & Fins & 2000 & 0.581 & 0.288 & 2.538 & 0.221 & 0.001 \\
\hline 26 & Fins & 2001 & -1.035 & 0.349 & 2.660 & -0.474 & 0.006 \\
\hline 27 & Fins & 2002 & 0.157 & 0.473 & 3.689 & 0.103 & 0.000 \\
\hline 28 & Legs & 1994 & 0.019 & 0.409 & 3.318 & 0.010 & 0.000 \\
\hline 29 & Legs & 1995 & -0.007 & 0.474 & 3.725 & -0.005 & 0.000 \\
\hline 30 & Legs & 1996 & -1.211 & 0.299 & 1.949 & -0.478 & 0.006 \\
\hline 31 & Legs & 1997 & 0.232 & 0.255 & 2.599 & 0.079 & 0.000 \\
\hline 32 & Legs & 1998 & 1.372 & 0.232 & 1.670 & 0.435 & 0.005 \\
\hline 33 & Legs & 1999 & 0.674 & 0.250 & 2.353 & 0.226 & 0.001 \\
\hline 34 & Legs & 2000 & -0.781 & 0.364 & 2.613 & -0.374 & 0.004 \\
\hline 35 & Legs & 2001 & -0.865 & 0.364 & 2.516 & -0.414 & 0.005 \\
\hline 36 & Legs & 2002 & 0.568 & 0.323 & 2.668 & 0.240 & 0.002 \\
\hline 37 & Mcps & 1994 & -1.463 & 0.454 & 1.818 & -0.918 & 0.023 \\
\hline 38 & Mcps & 1995 & 0.701 & 0.413 & 2.890 & 0.387 & 0.004 \\
\hline 39 & Mcps & 1996 & 0.025 & 0.305 & 2.821 & 0.010 & 0.000 \\
\hline 40 & Mcps & 1997 & 1.081 & 0.275 & 2.048 & 0.395 & 0.004 \\
\hline 41 & Mcps & 1998 & -0.167 & 0.233 & 2.539 & -0.053 & 0.000 \\
\hline 42 & Mcps & 1999 & -0.075 & 0.221 & 2.514 & -0.023 & 0.000 \\
\hline 43 & Mcps & 2000 & -0.122 & 0.342 & 2.966 & -0.055 & 0.000 \\
\hline 44 & Mcps & 2001 & -0.528 & 0.343 & 2.774 & -0.237 & 0.002 \\
\hline 45 & Mcps & 2002 & 0.548 & 0.408 & 3.035 & 0.298 & 0.003 \\
\hline \multicolumn{4}{|c|}{ Critical values } & 0.800 & 1.200 & 1.260 & 1.650 \\
\hline
\end{tabular}

Notes: Afre-Airfreight services; Educ-Education and training services; Fins-Financial services; Legs-Legal services; Mcps-Management, consulting and public relations services; Ocfr-Ocean freight services; Ocps-Ocean port services; Rdts-Research, development and testing services; Tels-Telecommunications services; Trav-Travel (tourism) services. Shaded observations are influential since they are above the critical values.

Source: Influential observations.

point is moved up or down, the regression surface will tend to follow it. Covratio statistic measures the effect of observations on the covariance matrix of the parameter estimates. The Dffits statistic is a scaled measure of the change in the predicted value for the fth observation. Large absolute values of Dffits indicate influential observations. The CookD statistic is an overall measure of the influence of the ith observation on all the parameter estimates.

Tables 6 and 7 present stacked influential data statistics for each observation. The first four columns refer to the observation number, service industry, year and residual, 
Table 7. Influential data observations (continued)

\begin{tabular}{|c|c|c|c|c|c|c|c|}
\hline Obs & Service industry & Year & Residual & $\mathbf{h}$ & Covratio & Dffits & CookD \\
\hline 46 & Ocfr & 1994 & 3.728 & 0.569 & 0.011 & 3.572 & 0.305 \\
\hline 47 & Ocfr & 1995 & 3.133 & 0.525 & 0.098 & 2.535 & 0.164 \\
\hline 48 & Ocfr & 1996 & -2.465 & 0.304 & 0.607 & -1.003 & 0.027 \\
\hline 49 & Ocfr & 1997 & -2.330 & 0.272 & 0.730 & -0.855 & 0.020 \\
\hline 50 & Ocfr & 1998 & -1.721 & 0.294 & 1.339 & -0.671 & 0.012 \\
\hline 51 & Ocfr & 1999 & -1.592 & 0.415 & 1.579 & -0.892 & 0.022 \\
\hline 52 & Ocfr & 2000 & 0.788 & 0.369 & 2.621 & 0.382 & 0.004 \\
\hline 53 & Ocfr & 2001 & 0.625 & 0.435 & 3.081 & 0.368 & 0.004 \\
\hline 54 & Ocfr & 2002 & -0.165 & 0.555 & 4.361 & -0.140 & 0.001 \\
\hline 55 & Ocps & 1994 & -0.992 & 0.572 & 3.077 & -0.888 & 0.022 \\
\hline 56 & Ocps & 1995 & -1.012 & 0.778 & 3.958 & -2.051 & 0.116 \\
\hline 57 & Ocps & 1996 & -0.288 & 0.753 & 7.491 & -0.509 & 0.007 \\
\hline 58 & Ocps & 1997 & 2.520 & 0.306 & 0.565 & 1.033 & 0.029 \\
\hline 59 & Ocps & 1998 & 0.894 & 0.285 & 2.262 & 0.337 & 0.003 \\
\hline 60 & Ocps & 1999 & -1.383 & 0.330 & 1.785 & -0.601 & 0.010 \\
\hline 61 & Ocps & 2000 & -4.541 & 0.335 & 0.009 & -2.153 & 0.112 \\
\hline 62 & Ocps & 2001 & 7.763 & 0.350 & 0.000 & 4.759 & 0.357 \\
\hline 63 & Ocps & 2002 & -2.961 & 0.588 & 0.100 & -2.928 & 0.218 \\
\hline 64 & Rdts & 1994 & -0.358 & 0.798 & 8.686 & -0.797 & 0.018 \\
\hline 65 & Rdts & 1995 & 1.012 & 0.778 & 3.958 & 2.051 & 0.116 \\
\hline 66 & Rdts & 1996 & 0.288 & 0.753 & 7.491 & 0.509 & 0.007 \\
\hline 67 & Rdts & 1997 & -0.920 & 0.451 & 2.735 & -0.568 & 0.009 \\
\hline 68 & Rdts & 1998 & -1.402 & 0.282 & 1.699 & -0.525 & 0.008 \\
\hline 69 & Rdts & 1999 & 1.021 & 0.266 & 2.089 & 0.362 & 0.004 \\
\hline 70 & Rdts & 2000 & 0.801 & 0.362 & 2.583 & 0.381 & 0.004 \\
\hline 71 & Rdts & 2001 & -0.255 & 0.356 & 2.992 & -0.119 & 0.000 \\
\hline 72 & Rdts & 2002 & -0.187 & 0.376 & 3.111 & -0.092 & 0.000 \\
\hline 73 & Tels & 1994 & -1.223 & 0.447 & 2.221 & -0.749 & 0.157 \\
\hline 74 & Tels & 1995 & -1.446 & 0.453 & 1.845 & -0.905 & 0.023 \\
\hline 75 & Tels & 1996 & 2.669 & 0.445 & 0.362 & 1.667 & 0.074 \\
\hline 76 & Tels & 1997 & 0.204 & 0.625 & 5.128 & 0.217 & 0.001 \\
\hline 77 & Tels & 1998 & 0.500 & 0.377 & 2.938 & 0.249 & 0.002 \\
\hline 78 & Tels & 1999 & 0.064 & 0.281 & 2.724 & 0.024 & 0.000 \\
\hline 79 & Tels & 2000 & 1.106 & 0.352 & 2.183 & 0.511 & 0.007 \\
\hline 80 & Tels & 2001 & -1.882 & 0.356 & 1.167 & -0.890 & 0.022 \\
\hline 81 & Tels & 2002 & 0.008 & 0.455 & 3.598 & 0.005 & 0.000 \\
\hline 82 & Trav & 1994 & 0.385 & 0.725 & 6.492 & 0.601 & 0.010 \\
\hline 83 & Trav & 1995 & -0.701 & 0.347 & 2.635 & -0.319 & 0.003 \\
\hline 84 & Trav & 1996 & 1.705 & 0.314 & 1.368 & 0.708 & 0.014 \\
\hline 85 & Trav & 1997 & 0.661 & 0.437 & 3.047 & 0.391 & 0.004 \\
\hline 86 & Trav & 1998 & 1.405 & 0.380 & 1.822 & 0.709 & 0.014 \\
\hline 87 & Trav & 1999 & -0.530 & 0.259 & 2.479 & -0.183 & 0.001 \\
\hline 88 & Trav & 2000 & -0.897 & 0.261 & 2.197 & -0.313 & 0.003 \\
\hline 89 & Trav & 2001 & -2.982 & 0.335 & 0.274 & -1.349 & 0.048 \\
\hline 90 & Trav & 2002 & 0.955 & 0.378 & 2.446 & 0.476 & 0.006 \\
\hline \multicolumn{4}{|c|}{ Critical values } & 0.800 & 1.200 & 1.260 & 1.650 \\
\hline
\end{tabular}

Notes: Afre-Airfreight services; Educ-Education and training services; Fins-Financial services; Legs-Legal services; Mcps-Management, consulting and public relations services; Ocfr-Ocean freight services; Ocps-Ocean port services; Rdts-Research, development and testing services; Tels-Telecommunications services; Trav-Travel (tourism) services. Shaded observations are influential since they are above the critical values.

Source: Influential observations output from sAS statistical software.

respectively. The last four columns refer to the hat-values, Covratio, Dffits and CookD statistics, respectively. The last row shows critical values for the four statistics. Any observation with a statistic greater than the critical value is influential. All these data points are shaded. For instance, data point 1994 for financial services is influential using the hatvalue. This implies that if this point is moved up or down, the regression surface will tend to follow it.

The problematic data points were investigated and found that the influential observations are not due to flaws in data collection. Consequently, the influential data 


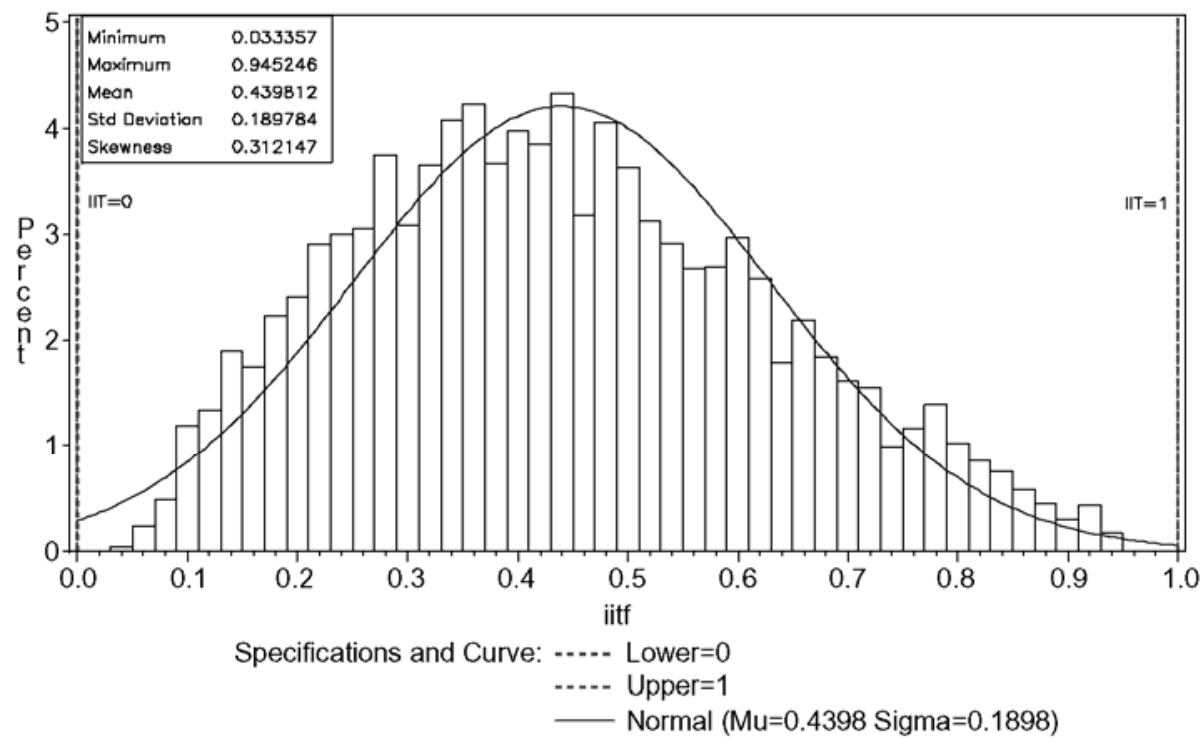

Figure 1. EDF of the predicted South Africa-US IIT in financial services Source: sAS statistical software output from Liu-Davidson-Flachaire wild bootstrap algorithm.

points were not discarded. Instead, information from the influential data statistics is used to inform the bootstrapping process. Firstly, the covratio statistic shows that pairs resampling cannot be used because regressors are not interchangeable as they affect the precision of the estimates. Secondly, the Dffits and leverage statistics show that pooling of residuals from different sectors in the residual resampling process may not be appropriate. Instead, stratified resampling or wild bootstrap should be used.

The overall explanatory power of the model (in terms of adjusted $R^{2}$ ) shows that the regressors explain about $50 \%$ of the variation in log odds of IIT. The F-statistic shows that the regressors are jointly significant in explaining the dependent variable. The Durbin h statistic shows that the model does not suffer from serial correlation problem.

\section{(b) Bootstrap Results}

Table 5 presents the bootstrap results. The fourth column in this table display standardised bias \{i.e. bias in equation 13 divided by bootstrap standard error). Since the standardised bias is below 0.25 a threshold suggested in Efron (1982), the estimates in equation 2 are unbiased and therefore endogeneity in the dynamic panel data model is not a serious problem.

The model is consistent with Grubel and Lloyd (1975) since it predicts IIT within the 0 and 1 range in all the services. Fig. 1 confirms this for predicted IIT in financial services. ${ }^{9}$ A normal distribution line is superimposed on the histogram to determine whether the parameter's EDF is bell-shaped with normal tails or not. Although the study utilises a classical interpretation of probability, as opposed to Bayesian approach, the EDF for IIT provides an approximation to the underlying DGP for South Africa-US unaffiliated IIT in selected services.

\footnotetext{
${ }^{9}$ The EDFs of predicted IIT for the other services are available from the authors.
} 


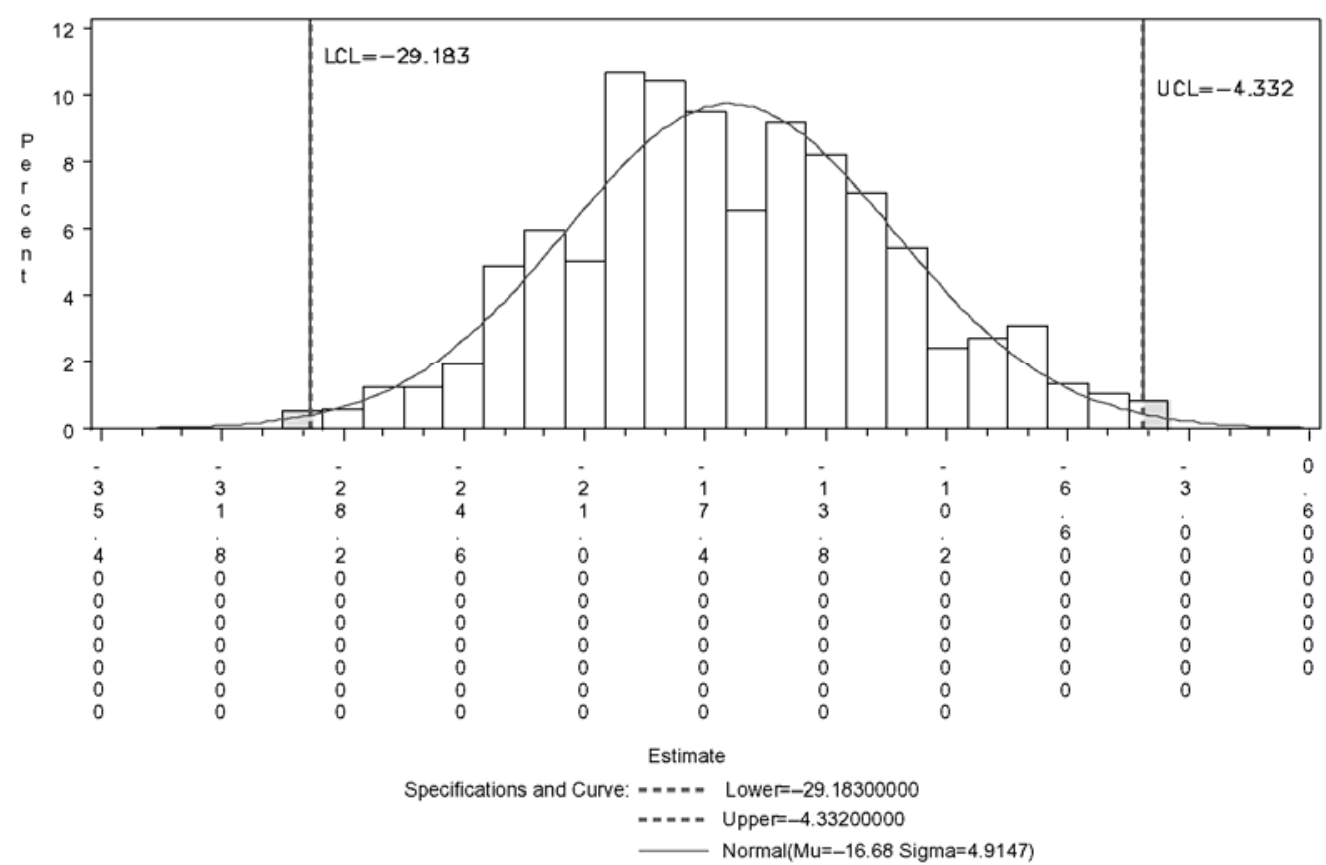

Figure 2. EDF of the coefficient for the difference in market size between South Africa and the US (99\% confidence intervals)

Source: sas statistical software output from Liu-Davidson-Flachaire wild bootstrap algorithm.

Unlike the classical approach in Table 3, the testing of hypotheses in wild bootstrap is done by looking at whether the null hypothesis, $\beta=0$, is contained in the confidence interval of the bootstrap results. For example, in the case of the difference in market size, the bootstrap confidence intervals do not contain $\beta=0$ implying that it is statistically significant.

This can be seen graphically in Fig. 2, which shows the EDF of this coefficient with its 99\% wild bootstrap confidence intervals. The LCL and UCL refer to $99 \%$ lower and upper confidence intervals, respectively. Since $\beta=0$ is not contained in the interval, the difference in market size is statistically different from zero. The same can be done for all the other coefficients.

The coefficient of 74.744 for the intercept term in Table 5 is interpreted as the global mean since effects coding is used in constructing fixed effects. The service-specific effects are deviations from this grand mean as opposed to regression coding, where the effects would be deviations from a reference class.

\section{(c) Interpretation of the Results}

The coefficient for the lagged dependent variable $\left(y_{i t-1}\right)$ is negative and statistically significant. The fact that there is a positive bias as shown in column 4 of Table 5 confirms a theoretical postulation by Nickell (1981) that in a dynamic panel data model, if the population parameter is negative, then the bias is positive and vice versa. 
Differences in demand structure, proxied by differential in per capita income, has a negative sign as anticipated and is statistically significant at $1 \%$ level. This is in line with the CHO model of horizontally differentiated IIT (HUT) and agrees with many "North-South" studies on IIT in goods presented in Table 10.1 of Greenaway and Milner (2002:184). The results are similar to those in Li et al. (2003, 2005). The results are, however, inconsistent with vertically differentiated IIT (VIIT) theoretical model of Flam and Helpman (1987) and the empirical findings by Clark and Stanley (1999) dealing with goods and Lee and Lloyd (2002) study on services. These studies postulate a positive relationship between per capita income and IIT. Additionally, despite our inability to disentangle HUT from VIIT, the consistency with CHO model implies that the former dominates South Africa-US IIT in services.

The difference in market size is negatively related to odds ratio of unaffiliated IIT. The results agree with both models of "love-of-variety" (Krugman, 1979) and "the ideal-variety" (Lancaster, 1980), which suggest that larger markets have the potential to allow for greater differentiation in services. The finding is consistent with the results in Li et al. (2003, 2005). The difference in market size proxy differences in existence of economies of scale and the different ability of South Africa and US to provide differentiated services. The results confirm the fact that the limited market size in South Africa reduces the opportunities for firms to produce and export differentiated and competitive services as compared to the US. This means that there is need to expand the market size for services sector in South Africa so that firms can reap economies of scale.

The results show that US FDI in South Africa has a positive relationship with log odds of unaffiliated IIT in services. The positive relationship is consistent with the theoretical trade models of Helpman and Krugman (1985), Markusen and Venables (1998, 2000). This means that presence of US multinationals complement rather than substitute exports of services by South African firms. The finding also agrees with the results in Li et al. $(2003,2005)$. This is, however, not consistent with the view that FDI should substitute unaffiliated IIT. The results show that US multinational corporations overcome costs of trade barriers in services by establishing themselves in South Africa (host country) and then generate arms-length trade with the US (home country).

The results show that nominal exchange rate has a positive and significant effect on IIT. This means that a depreciation of the South African Rand against the dollar makes South African exporters of services competitive and discourages imports from the US.

Trade openness to all the four modes of supply (cross-border, consumption abroad, commercial presence and presence of natural persons) in South Africa and the US are inimical to unaffiliated IIT in services. In terms of the sign, the results are in line with Falvey's (1981) model of VIIT, which demonstrates that countries with lower tariff barriers have higher levels of IIT. The coefficient is, however, statistically insignificant and is contrary to the results of Lee and Lloyd (2002:170) who find a positive and insignificant relationship. The difference in the finding with Lee and Lloyd (2002) may emanate from the method used to define a proxy for trade orientation. Their trade orientation is proxied by residuals from a regression of the log of per capita services trade on the log of per capita income and log of population. Our study uses the Hoekman (1995) trade barriers indices constructed using GATS schedules.

The degree of deregulation in South Africa has the expected positive sign in most services except airfreight; legal services; ocean freight and telecommunication services. 
However, the finding is statistically significant in airfreight; educational and training services; management and consulting services; ocean freight; ocean port services; research development and testing services and telecommunication. This finding is in line with the results in Li et al. (2003).

The service-specific effects are deviations from the global mean (74.744). On one hand the service-specific effects are positive for airfreight; ocean freight and telecommunication services. This means that there are time-invariant service-specific characteristics which bolster South Africa-US I IT in the service sectors. On the other hand, there are negative service-specific effects in education services; financial services; legal services; management, consulting and public relations; ocean port services; research development and testing services and travel. This means that there are time-invariant unique characteristics in these services that tend to discourage South Africa's exports and instead promote imports of services from the US and should be identified using sector-specific surveys.

The time-specific effects are also interpreted with reference to the grand mean (intercept). The coefficients for the period 1994-1998 are negative but positive thereafter. However, in terms of statistical significance, the coefficients for the periods of 1994, 1996, 1998, 2000 and 2001 are significant. This pattern confirms the fact that following South Africa's political dispensation in 1994, imports of services from the US dominated but this changed from 1999 onwards.

\section{CONCLUSIONS}

The empirical results show that South Africa-US IIT in services is determined by factors similar to those in other "North-South" IIT studies (such as Clark and Stanley, 1999). Specifically, IIT is determined by differences in per capita income, US FDI in South Africa, the degree of economic freedom in South Africa, and service-specific and time-specific effects.

Firstly, there is a significant negative relationship between the log odds ratio of IIT and the per capita income difference, indicating the significance of demand similarities or differences in capital-labour ratios in generating South Africa-US IIT in the selected services.

Secondly, the difference in market size is negatively related to the odds ratio of IIT, which confirms the theoretical argument that IIT is associated with economies of scale. This shows that the limited market size in South Africa reduces the opportunities for firms to innovate and produce differentiated and competitive services as compared to the US. There is thus a need to expand the market size for services in South Africa so that exporters can reap economies of scale, which can be done through programmes that increase the purchasing power of South Africans as well as regional economic integration (e.g. SACU).

Thirdly, there is a positive relationship between FDI and IIT thus supporting the new trade theories that emphasise the role of multinational corporations in complementing the increase in the volume of trade rather than as a substitute for trade. This finding calls for the need to strengthen South Africa-US investment initiatives.

Fourthly, the service-specific characteristics are inimical to IIT in education and training services; management consulting and public relations; ocean port and travel. There is therefore a need to identify these characteristics using industry level survey. 
Finally, time-specific effects are negative for the period 1994-1998 but positive thereafter. This pattern confirms the efficacy of liberalisation policy in South Africa.

Some policy implications do emerge from the negative and significant relationship in the difference in per capita income. First, although data problems limited our ability to disentangle HUT from VIIT, the agreement of the results with the former means South Africa-US trade in services involves dissimilar economies ${ }^{10}$ and initiatives to promote such trade in the form of regional integration \{e.g. SACU-US FTA) while trade liberalisation is inimical to intra-industry specialisation. Second, the low South Africa-US HUT in services entails higher factor market adjustment in terms of job losses. ${ }^{11}$

\section{REFERENCES}

ABD-EL-RAHMAN, K. (1991). Firms and competitive and national comparative advantage as joint determinants of trade composition. Weltwirtschafrliches Archiv, 127:83-97.

ANDRESEN, M. A. (2003). Empirical intra-industry trade: What we know and what we need to know. [Online] Available from: http://www.geog.ubc.ca/-andresen/Papers/Empirical_IIT_Lit_Review.pdf [Accessed 25 August 2005].

ARELLANO, M. and BOND, S. (1991). Some tests of specification for panel data: Monte carlo evidence and application to employment equations. Review of Economic Studies, 58: 227-297.

ARRELLANO, M. and BOVER, O. (1995). Another look at the instrumental variable estimation of error-components models. Journal of Econometrics, 68:29-51.

BALASSA, B. and BAUWENS, L. (1987). Intra-industry specialisation in a multi-industry framework. Economic Journal, 97: 923-939.

BALTAGI, B. H. (2001). Econometric Analysis of Panel Data. New York: John Wiley.

BERAN, R. (1986). Discussion of "Jacknife Bootstrap and Other Resampling Methods in Regression Analysis" by Wu, C. EJ. Annals of Statistics, 14: 1295-1298.

CLARK, D. P. and STANLEY, D. L. (1999). Determinants of intra-industry trade between developing countries and the United States. Journal of Economic Development, 24:79-95.

DAVIDSON, R. and FLACHAIRE, E. (2001). The wild bootstrap, tamed at last. [Online] Available from: http://sticerd.lse.ac.uk/dps/darp/DARP58.pdf [Accessed 4 September 2004].

DAVISON, A. C. and HINKLEY, D. V. (1998). Bootstrap Methods and Their Application. New York: Cambridge University Press.

EFRON, B. (1979). Bootstrap methods: Another look at the Jacknife. Annals of Statistics, 7: 1-26.

Statistics.

EVERAERT, G. and POZZI, L. (2004). Bootstrap based bias correction for homogenous dynamic panels. Ghent

University, Working Paper no.2004/263.

FALVEY, R. E. (1981). Commercial policy and intra-industry trade. Journal of International Economics, 11:495-511.

FLACHAIRE, E. (2003). Bootstrapping heteroscedastic regression models: Wild bootstrap vs pairs bootstrap. [Online] Available from: http://eurequa.univ-parisl.fr/membres/flachaire/research/Flachaire_03a.pdf [Accessed 12 October 2004].

FLAM, H. and HELPMAN, H. (1987). Vertical product differentiation and the North-South trade. American Economic Review, 77: 810-822.

GREENAWAY, D. and MILNER, R. C. (1989). The growth and significance of intra-industry trade. In J. Black and A. I. McBean (eds), Causes and Changes in the Structure of International Trade, 1960-1985. London: MacMillan. (2002). Intra-industry trade and the C-H-O model: Evidence and implications for adjustments. In P. J. Lloyd and

H. Lee (eds), Frontiers of Research in Intra-industry Trade. London: Palgrave Macmillan, 180-196.

GRUBEL, H. G. and LLOYD, G. C. (1975). Intra-industry Trade: The Theory and Measurement of International Trade in Differentiated Products. New York: Wiley.

HELPMAN, E. and KRUGMAN, P. R. (1985). Market Structure and Foreign Trade. Wheatsheef Boods: MIT: Harvester Press.

HODGE, J. and NORDAS, H. (2001). Liberalization of trade in producer services - The impact on developing countries. The South African Journal of Economics, 69: 93-122.

HOEKMAN, B. (1995). Assessing the general agreement on trade in services. In W Will Martin and L. A. Winters (eds), The Uruguay Round and the Developing Economies. World Bank Discussion Paper No. 307. Washington.

HOROWITZ, J. L. (2001). The bootstrap and hypothesis tests in econometrics. Journal of Econometrics, 100: 37-40.

10 This is pointed out by Greenaway and Milner (2002:192).

1 In other words, most firms supplying services would be located in the US to supply services in South Africa. 
INTERNATIONAL MONETARY FUND. (1993). Balance of Payments Manual- Fifth Edition, Washington DC: IMF. KRUGMAN, P. (1979). Increasing returns, monopolistic competition, and international trade. Journal of International Economics, 9:469-479.

KUNIN, M. and ZIGIC, K. (2003). Strategic trade policy and product differentiation: Intra-industry trade between developed and developing countries. [Online] Available from: http://www.cerge-ei.cz/pdf/wp/Wp230.pdf [Accessed 16 July 2004].

LANCASTER, K. (1980). Intra-industry trade under perfect competition. Journal of International Economics, 10: 151-175. LEE, H. H. and LLOYD, P. J. (2002). Intra-industry trade in services. In P. J. Lloyd and H.-H. Lee (eds), Frontiers of Research in Intra-industry Trade. London: Palgrave Macmillan, 159-179.

LEVENE, H. (I960). Robust tests for equality of variances. In I. Oklin (ed.), Contributions to Probability and Statistics: Esays in Honor of Harold Hotelling. Stanford, CA: Stanford University Press, 278-292.

LI, D., MOSHIRIAN, F. and SHIM, A. (2003). The determinants of intra-industry trade in insurance services. The Journal of Risk and Insurance, 70: 269-287.

------- (2005). Intra-industry trade in financial services. [Online] Available from: http://wwwdocs.fce.unsw.edu.au/ banking/staff/profiles/dli/iit\%20in\%20banking\%20Final.doc [Accessed 8 March 2005].

LIU, R. Y (1988). Bootstrap procedures under some non-I.I.D. Models. Annals of Statistics, 16: 1696-1708. MACKINNON, J. G. and WHITE, H. (1985). Some heteroscedasticity consistent covariance matrix estimators with improved finite sample properties. Journal of Econometrics, 29: 305-325.

MAMMEN, E. (1993). Bootstrap and wild bootstrap for high dimensional linear models. Annals of Statistics, 21: 255-285. MARKUSEN, J. R. and VENABLES, A. J. (1998). Multinational firms and the theory of international trade. Journal of International Economics, 46:183-203.

--(2000). The theory of endowment, intra-industry and multinational trade. Journal of International Economics, 52: 209-234.

MOONEY, C. Z. and DUVAL, R. D. (1993). Bootstrapping: A nonparametric approach to statistical inference. Sage University Paper Series on Quantitative Applications in Social Sciences, series no.07-095. Newbury Park, CA: Sage. MUKHERJEE, C, WHITE, H. and WUYTZ, M. (1998). Econometrics and Data Analysis for Developing Countries. London: Routledge.

NICKELL, S. (1981). Biases in dynamic models with fixed effects. Econometrica, 49: 1417-1426.

SAPIR, A. (1985). North-South issues in trade in services, the World Economy, 8: 27-42.

SICHEI, M. M. (2005). South Africa-US Intra-industry Trade in Services. Unpublished PhD Thesis, University of Pretoria. UNITED NATIONS CONFERENCE ON TRADE AND DEVELOPMENT (UNCTAD). (2004a). Handbook of

Statistics CD ROM 2004. [Online] Available from: http://www.unctad.org

-------- (2004b). World Investment Report: The Shift Towards Services. [Online] Available from: http://www.unctad.org/ en/docs/wir2004_en.pdf [Accessed 8 January 2005].

US DEPARTMENT OF COMMERCE. (1998). U.S. international transactions in private services: A guide to the surveys conducted by the Bureau of Economic Analysis. [Online] Available from: http://www.bea.gov/bea/articles/ INTERNAT/INTSERV/Meth/itguide.pdf [Accessed 1 September 2005]

WALLEY, J. and KEITH, J. C. (2003). Competitive liberalisation and a US-SACU FTA. NBER Working Paper series no. 10168.

WORLD TRADE ORGANISATION. (2002). The legal Texts: The Results of the Uruguay Round of Multilateral Trade Negotiations. Geneva: WTO Secretariat.

WU, C. F. J. (1986). Jacknife bootstrap and other resampling methods in regression analysis. Annals of Statistics, 14:1261-1295. 